\title{
13 \\ Reparations for Indigenous Peoples in Two Selected Latin American Countries
}

\author{
Marzia Rosti*
}

\section{Argentina}

\section{a) Indigenous populations in Argentina in the nineteenth and twentieth centuries}

Argentina's 1994 constitutional reform introduced sentence 17 into Art 75 of its Constitution, according to which:

[c]orresponde al Congreso... reconocer la preexistencia étnica y cultural de los pueblos indígenas argentinos. Garantizar el respeto a su identidad y derecho a una educación bilingüe e intercultural; reconocer la personería jurídica de sus comunidades, y la posesión y propriedad comunitarias de las tierras que tradicionalmente ocupan; y regular la entrega de otras aptas y suficientes para el desarrollo humano; ninguna de ellas será enajenable, trasmisible ni susceptible de gravámenes y embargos. Asegurar su participación en la gestión referida a sus recursos naturales y a los demás intereses que los afecten. Las provincias pueden ejercer concurrentemente estas atribuciones. ${ }^{1}$

This provision was the result of the Argentina's desire to break down the tendencies of assimilation and cultural homogenization promoted in the second half of the nineteenth century with the purpose of building a homogeneous white

\footnotetext{
* Researcher in the Philosophy of Law at the University of Milan, where she teaches the Culture of Spanish-speaking countries. This chapter is current as of October 2006, and has been translated from Italian into English by Federico Lenzerini.

1 Congress is empowered... [t]o recognize the ethnic and cultural pre-existence of indigenous peoples of Argentina. To guarantee respect for the identity and the right to bilingual and intercultural education; to recognize the legal capacity of their communities, and the community possession and ownership of the lands they traditionally occupy; and to regulate the granting of other lands adequate and sufficient for human development; none of them shall be sold, transmitted or subject to liens or attachments. To guarantee their participation in issues related to their natural resources and in other interests affecting them. The provinces may jointly exercise these powers." (Official translation, available at <http:// www.argentina.gov.ar/argentina/portal/documentos/constitucion_ingles.pdf $>$, last visited on 28 August 2007.
} 
nation offering great opportunities to European immigrants and foreign investors, without consideration for the indigenous part of the population. The members of those minorities who survived the slaughters (perpetrated first by Spanish colonizers and then by Argentines themselves ${ }^{2}$ ), lived for about a century with the misleading status of Argentine citizens and under the illusion of 'official' equality with whites and half-caste people. ${ }^{3}$ This equality led to a suppression of the ethnic, cultural and legal diversities of the colonial period, translating into the effective reduction of the indigenous minorities, which, by means of ignoring their differences, were intended to be integrated into the dominant European society.

Only when Perón took power in 1946-1955 did a policy of 'integración socio-cultural' begin, which was followed, at the beginning of the 1970s, by the policy of 'reparación histórica' for wrongs suffered by indigenous peoples, including in particular deprivation of lands and marginalization from national socio-economic progress. ${ }^{4}$ The military coup d'etat of 1976 blocked all activities developed by the institutions and representative organizations of the indigenous peoples. ${ }^{5}$ The end of military government in 1983 gave rise to the beginning of a new 'indigenist policy', aimed at considering the indigenous person as a 'diverse subject', whose diversity was to be safeguarded and respected. It was a significant step forward towards the recognition of cultural and legal pluralism for a country that had previously preferred to present itself as 'white' and 'European' and to identify itself with foreign contributions rather than with its indigenous culture. In previous years, the indigenous communities themselves had developed a progressively growing consciousness of their own rights, thanks to the activism

2 Based on the project to construct a 'white and homogeneous nation', the Argentine Constitution of 1853/60 entrusted the Congreso de la Nación with the task of '[p] roveer a la seguridad de las fronteras; conservar el trato pacífico con los indios, y promover la conversión de ellos al catolicismo' (Art 67, No 15). This provision legitimized two terrible military campaigns: the Conquista del deserto, in 1880, carried out in the regions of Patagonia and Pampa, which moved the Southern border of the country to the Río Negro, and the Campaña del Chaco, in 1884, which moved the Northern Argentine border to the Río Bermejo. The official records of the army indicate that 10,656 indigenous people were killed during the 1880 campaign and 1,679 during the 1884 campaign. These figures do not include deaths caused by hunger, hardship, privations and diseases.

3 Since 1810, when Argentina obtained independence from Spain, successive governments have proclaimed the principles of equality and freedom of indigenous peoples a number of times, particularly through abrogating those colonial institutions such as mita and encomienda, which bound indigenous inhabitants to the service of white people.

4 See M. Carrasco, Los derechos de los pueblos indigenas en Argentina (Buenos Aires: Grupo Internacional de Trabajo sobre Asuntos Indígenas, Asociación de Comunidades Aborígenes Lhaka Honhat, 2000). The main measure taken by Perón in favour of indigenous peoples was the distribution of identity documents to indigenous inhabitants, who became Argentine citizens and strengthened the electoral force of the Partido Justicialista.

5 In 1971, for example, the Confederación Indigena Neuquina was established, followed by the Asociación Indigena de la República Argentina in 1975. The latter association sent its representatives to the Consejo Mundial de Pueblos Indigenas, held in Canada in that same year. 
of their first representative organizations and to the growing attention of the international community with regard to the issue of the protection of minorities. ${ }^{6}$

This new indigenist policy was inaugurated by the province of Formosa, which first approved, in 1984, the Ley Integral del Aborigen, ${ }^{7}$ followed by the provinces of Jujuy, Río Negro, Buenos Aires, El Chaco, Pampa, Neuquén, Chubut, and Salta. All these provinces, between 1986 and 1988, amended their constitutions through the introduction of provisions specifically dealing with local indigenous populations. ${ }^{8}$ However, these provisions varied in content with respect to one another: for instance, the Constitution of Chubut even recognizes indigenous intellectual property, while the Constitution of Salta recognizes the legal personality and land ownership of indigenous peoples only to the extent that they are granted by subsequent laws. Provincial constitutional reforms were then followed by ad hoc provincial laws, some of which contemplated the institution of specific bodies for the protection and representation of local indigenous communities,

${ }^{6}$ Argentina has the lowest proportion of indigenous peoples living in its territory, in comparison with other Latin-American countries. According to the official data collected by the Encuesta Complementaria de Pueblos Indigenas between 2004 and 2005, 402,921 indigenous persons live in the country, corresponding to 1 per cent of the total population, which is estimated as being 37,282,970 people by the Censo Nacional de Población Hogares y Viviendas of 2001. It is estimated that in 2006 the total Argentine population was about 39 million people, of whom 2.8 per cent recognize themselves as belonging to an autochthonous community, including: the Mbya-Guaraní, Mocoví, Pilagá, Toba, Vilela and Wichí communities living in the regions of the North-East (provinces of Chaco, Formosa, Misiones, and Santa Fe); the Atacama, Avá-Guaraní, Chané, Chorote, Chulupí, Diaguita, Calchaquí, Kolla, Omaguaca, Ocloya, Tapiete, Toba, TupíGuaraní, and Wichí communities living in the North-West regions (provinces of Jujuy, Salta, Santiago del Estero, Tucumán, La Rioja, San Juan, and Catamarca); the Mapuche, Ona, Tehuelche, and Yamana communities living in the Southern regions (provinces of Chubut, Neuquén, Santa Cruz, and Tierra del Fuego); the Huarpe and Rankulche communities living in the regions of the central part of the country (provinces of Mendoza, La Pampa, and Buenos Aires). The largest community is the Mapuche (26 per cent of the whole indigenous population of Argentina), while the smallest ones are the Chulupí ( 0.1 per cent), the Tapiete $(0.12$ per cent) and the Ona $(0.12$ per cent). In 1895 it was believed that the total indigenous population of Argentina was 180,000 people, representing 4.3 per cent of the whole population (estimated as then being 4,014,911 people). In 1965 the first Censo Indígeno Nacional was started, which was never completed. The partial data collected indicated 165,381 indigenous persons (75,675 of whom were effectively registered and 89,706 only reckoned). In 1970 in the Formosa province 8,611 indigenous inhabitants were counted, while 17,235 were registered in the Salta province in 1984.

7 Ley Integral del Aborigen of the Formosa province (No 426 of 1984). See A Idoyaga Molina, 'Análisis antropológico de la ley integral del aborigen de la provincia de Formosa (Argentina)', in A. Levaggi (ed), El aborigen y el derecho en el pasado y el presente (Buenos Aires, 1990), pp 285-337.

8 These amendments included: Art 50 of the Constitution of the Jujuy province, adopted in 1986; Art 42 of the Constitution of the Río Negro province (1988); Art 79 of the Constitution of the Formosa province (1991). In 1994 the constitutions of the provinces of Buenos Aires (Art 36 No. 9), Chaco (Art 37), Pampa (Art 6 para. 2), Neuquén (Art 23 lett. d) and Chubut (Art 34 ) were also amended. More recent (1998) is the amendment of the Constitution of the Salta province (Art 15). See Carrasco, op cit, pp 46-48 and 53-56.

9 See, eg, the Instituto de Comunidades Aborigenes of the Formosa province, established with the law quoted in n 6 above; Instituto Provincial de Aborigen, established with Ley de promoción y desarrollo del aborigen No 6373 of 1986 (Salta province). See M Carrasco, "Indigenismo y democracia: clientes, políticos, punteros, caciques, gente", (1994) 15 Cuadernos (Instituto Nacional de Antropología y Pensamiento Latinoamericano, Buenos Aires), , pp 9-22. 
while others already provided them with the attribution of lands. ${ }^{10}$ Some of them, finally, simply reproduced applicable national legislation. ${ }^{11}$ In this respect, at the federal level the Ley de Politica Indigena y Apoyo a las Comunidades Aborígenes (n. 23.302) was enacted in 1985, followed in 1990 by the institution of the Foro Permanente por los Derechos de los Pueblos Indigenas, to which both indigenous representatives and organizations and associations fighting for the recognition of indigenous rights adhered. Finally, in 1992 the Ley Ratificatoria del Convenio 169 sobre pueblos indigenas y tribales en paises independientes was enacted. ${ }^{12}$

The twentieth century ended with the enactment (in 1994) of the new constitutional provision reproduced above, which replaced the obsolete and inappropriate rule of $1853 / 60 .{ }^{13}$ In drafting this new provision the Constituent Assembly considered a lot of proposals coming from indigenous associations. It was pressured by the Equipo Nacional de Pastoral Aborigen and the Asociación Indigena de la República Argentina, which created specific lobbies aimed at securing the constant presence of indigenous representatives before the Constituent Assembly. ${ }^{14}$

10 See, eg, Law 405 of 1998 (Tierra del Fuego province), named Adjudicación de tierras a las comunidades indigenas del pueblo Ona de la Provincia.

11 See, eg, Ley de Adesión de la provincia al régimen de la ley nacional 23.302 (No 5754) (Mendoza); Ley de Subprograma Integral de Mejoramento en la calidad de la vida de las comunidades aborígenes (No 4384 of 1998), Ley de Creación del Instituto de comunidades indígenas (No 2657 of 1991) and Ley de Creación del registro de Comunidades indigenas de la provicia del Chubut (No 4013) (Chubut); Ley Convenio Ministerio del Interior-Campaña hacia una sociedad con todos (No 1610 of 1994) (La Pampa); Ley Dirección provincial de Asuntos Guaranies-Creación-Comunidades guaranies-Deroga Ley 2435 (No 2727 of 1989) (Misiones); Ley de Instituto nacional de Asuntos indigenas. Adhesión ley 23303 (No 2553 of 1992) (Río Negro); Ley de comunidades aborígenes (No 11078 of 1994) (Santa Fe); Ley de Reservas indigenas (No 4086 of 1966), and Ley de promocióny desarrollo del aborigen (No 6373 of 1986) (Salta).

12 Ley 24.071. The 1989 ILO Convention No 169 on Indigenous and Tribal Peoples in Independent Countries entered into force on 3 July 2001 and replaced, for state parties, the 1957 ILO Convention No 107 concerning the Protection and Integration of Indigenous and Other Tribal and Semi-Tribal Populations in Independent Countries, already ratified by Argentina in 1959. Both conventions are available at <http://www.ilo.org/ilolex/english/convdisp1.htm> (last visited on 13 December 2006)

13 See $n 2$ above.

14 Among the proposals submitted to the Constituent Assembly the following are worth mentioning: Asamblea Permanente por los Derechos Humanos, Comisión de Asuntos Indígenas. Conclusiones del Encuentro por la reforma constitucional, Buenos Aires, 21-23 April 1994; Congreso Indigena de Integración Patagónica, Conclusiones sobre la reforma constitucional, El Bolsón, Río Negro, 16-19 April 1994; Asociación Indigena de la República Argentina, Los indígenas en la reforma constitucional, Buenos Aires 1994; Equipo Nacional de Pastoral Aborigen, Garantizar los derechos indígenas en la reforma constitucional, Buenos Aires, October 1993; Pueblos IndígenasTribales de los Bosques Tropicales, Resolución de la Conferencia de Penang, Malaysia, February 1992; Conferencia Iberoamericana de Comisiones Nacionales para la Conmemoración del Descubrimiento de América. Encuentro de dos mundos, VII Reunión, Guatemala, 1989; Consejo Mundial de Pueblos Indios, Declaración de principios, IV Asamblea Mundial, Panamá, 1984. The Comisión de Nuevos Derechos y Garantias, after having examined about sixty proposals presented by the various indigenous groups, presented a Bill to the Constituent Convention on 7 July 1994, which was modified by the Comisión de Redacción of the Convention. The Bill was not substantially different from the text that was then adopted, stating as follows: ' $r$ r]econocer en concurrencia con las provincias, la 


\section{b) Indigenous rights recognized in 1994: aspects and problems}

The indigenous rights recognised by the Constitution of Argentina have a collective or group dimension. ${ }^{15}$ Their operation ${ }^{16}$ could consequently result in legal conflicts, on account of both the restrictions they imply on the liberties and rights of individuals 'external' to the groups concerned and the threats they present to certain consolidated social equilibriums. This may be an explanation, though it is certainly not a justification, for Argentina's difficulty and tardiness - at both the federal and provincial level-in implementing the rights of indigenous peoples which were affirmed in 1994.

Through the affirmation of the 'preexistencia étnica y cultural de los pueblos indígenas argentinos' the thesis that, irrespective of the constitutional recognition, indigenous populations already existed on the state territory before 1994-possessing their own culture, rights and administrative system-has been accepted. Furthermore, some scholars have argued that, through the adoption of the constitutional provision at issue, the federal state recognised its historical responsibility for the genocide suffered by the Native Peoples, legitimating a different legal status (ie a positive discrimination) — as reparation for the afflictions suffered-which grants ethnic, cultural and legal pluralism. ${ }^{17}$ To this end the Constitution explicitly recognizes 'la posesión y propriedad comunitarias de las

preexistencia de los pueblos indígenas constitutivos de la Nación Argentina, garantizando el respeto a su identidad étnica y cultural; la personería jurídica de sus comunidades; la posesión y propriedad comunitaria de las tierras que tradicionalmente ocupan, disponiendo la entrega de las aptas y suficientes para el desarrollo humano, las que no seran enajenables ni embargables; asegurar su acceso a una educación bilingüe e intercultural; y a su participación en las decisiones para la utilización racional, administración y conservación de los recursos naturales en la gestión de sus intereses y en la vida nacional' (' $r$ ]ecognize in concurrence with provinces, the pre-existence of indigenous peoples who constituted the Argentine Nation, guaranteeing respect for their ethnic and cultural identity; legal personality of their communities; possession and communal property of lands they have traditionally inhabited, arranging the delivery of the lands suitable and sufficient for human development, which will be neither alienable nor seizable; ensure their access to bilingual and intercultural education; and their participation in the decisions for the rational use, administration and conservation of natural resources in the management of their interests and in national life'. See G Segovia and JF Segovia, 'La protección de los indígenas', in D. Pérez Guilhou (ed), Derecho constitucional de la reforma de 1994 (Buenos Aires, 1995), p 331.

15 'Collective rights' are meant as rights owned by a collectivity, which usually exercise them through its representative organs. They can be rights of liberty (granting patrimonial, legislative and territorial autonomy), social rights (ie rights to public assistance) and political rights (rights of participation and representativeness). 'Group rights' are based on the fact of belonging to a collectivity; they may be of individual or collective character. See AE Galeotti, 'I diritti collettivi', in E Vitale (ed) Diritti umani e diritti delle minoranze. Problemi etici politici e giuridici (Turin, 2000), pp 30-46.

16 The word 'operation', as used in the text, means the affirmation of a right and its codification in a formal written document, followed by the establishment of legal remedies for the enforcement of the right when it is infringed.

17 See L Ramos, 'Reforma constitucional: una nueva relación entre el Estado argentino y los pueblos originarios', available at $<$ http://www.alertanet.org $>$, p 3. 
tierras que tradicionalmente ocupan', that is to say the communal right of ownership of land already occupied by indigenous peoples before it was seized and assigned to white people in the form of individually owned estates after the military campaigns of the late 1800s. '[L]a entrega de otras [tierras] aptas y suficientes para el desarrollo humano', at the request of the communities concerned, is also contemplated.

There are certain aspects of the constitutional provision that, if fully implemented, could produce a number of problems not only of a legal but also of a social nature. First, through the recognition of the communal property of lands 'traditionally occupied' by the communities concerned, the titles of property acquired in more recent times by other people as a matter of applicable law would be invalidated. Also, with respect to the assignment of new lands to such communities it is imperative to choose lands which prove appropriate for meeting their needs, bearing in mind the difficulties involved in the inevitable assignment of lands other than those expressly requested. These difficulties arise by dint of the special relationship that the communities concerned have with that specific land, the different relative significance of that particular territory and also, by virtue of the fact that the culturally specific meaning of the land may not properly be taken into account.

It is also important to consider that, once a given land has been selected, third parties could - even in this event—claim rights on it, based on property titles previously obtained from institutions or former owners. In addition, some members of the communities concerned could claim their right to obtain a plot of land, at the borders of the territories assigned to the community, on an individual basis.

Consequently, in order to give full implementation to the constitutional diktat, the Argentine government should work on various levels. First, at the national level, the Instituto Nacional de Asuntos Indígenas, established by statute 23,302 of 1985, should promote the maximum possible participation of indigenous peoples in the implementation of the indigenist policy. It should be noted that this is often prevented in practice by the lack of funds and bureaucratic sluggishness, which reduce the concrete chances of organizing specific activities to this end, particularly consultations and meetings. Also, given that relevant federal competences often overlap with those assigned to provincial governments, adequate discretion should be left to the latter, since such local administrative bodies are better placed and enjoy a more intimate knowledge of the reality of local indigenous communities than the central government.

Finally, the legal system should also provide its contribution, both at the level of local tribunals - through defending indigenous rights in the local disputes - and in the Supreme Court of Justice of the Nation, which should settle the problems deriving from national (concerning the implementation of Art 75, sentence 17 of the Constitution and related legislation) and international law (with regard to the possible conflict between domestic law and applicable international treaties). 


\section{c) The recognition of community ownership of land in the provinces of Patagonia}

The land known as Patagonia is composed of the provinces of Río Negro, Neuquén e Chubut and comprises about 55 million hectares. It was originally inhabited by indigenous populations which, during the Conquista del desierto, were exterminated or - through violence, deception and abuses $-{ }^{18}$ dispossessed of their traditional lands. Such lands became property of the state or province and were later assigned, sold or rented to non-indigenous people. These past events represented the basis of the land claims of indigenous communities, leading to the development of a case-law which, through the application of the notion of 'preexistencia étnica', has actually affirmed the land rights claimed by some Mapuche communities and denied the validity of titles granted by institutions to non-indigenous persons.

Already in 2000, in the judgment Narez, Leyla Marcela s/denuncia usurpación, a judge of the Chubut province recognised the right of ownership of the claimant over contended land as arising from the constant occupation since time immemorial, rather than from 'una ocupación animus dominii' and irrespective of rules of private law. The judge, expressly relying on the constitutional provision and on the position affirmed by scholars, stated that 'por explicita decisión del constituyente las comunidades de referencia pasan a ser propietarias y poseedoras de las tierras que ocupan tradicionalmente', deciding that the counterclaim had to be dismissed 'por no constituir delíto el hecho investigado'.

More recently, in the case Oñate, Dolorindo y otros c/Rago, Pablo y otros s/Interdicto de retener, which was decided with a judgment released on 4 September 2002, the principle was affirmed that nobody with a property title or a contract of purchase may claim such a title over a piece of land through setting up or moving fences, particularly when an indigenous community traditionally occupies such land and claims its ownership. ${ }^{19}$ The subject of the dispute was a plot of land whose occupation and exploitation had often been a source of conflict between the Oñate family, (belonging to the indigenous community Kom Kiñé $\mathrm{Mu}$ which had traditionally occupied part of such land, and at least since 1925), and Pablo José Rago and José Luis Calviño, who also claimed the right of ownership over the land in question on the basis of a lease granted by the state to a former owner at the end of the 1950s. The defendants had tried to fence in the part of the land over which they claimed ownership, thus invading the portion occupied by the community. The members of the community reacted by removing the fences which had been put up_-during the night—by the defendants and preventing

18 See D Rodríguez Duch, 'Los conflictos territoriales de los pueblos indígenas en la Patagonia', in 167 Memoria, January 2003, available at <http://www.memoria.com.nx>.

19 Expte. 14.886-14-00, Juzgado Civil y comercial n 5 de la III Circunscripción Judicial de Río Negro. 
their reconstruction. In examining the case, Justice Riat recognised that 'las pruebas producidas acreditan inequivocamente que los actores ocupan efectivamente la veranada en disputa, sea como poseedores, sea como tenedores' ('the evidence supplied demonstrates unequivocally that the claimants effectively occupy the veranada [summer pastures] under dispute, as holders'), adding that 'el reconocimiento legal de una comunidad en esa zona permite inferir la mayor antigüedad de su ocupación' ('the legal recognition of a community in this zone allows the inference that its occupation occurred at a previous time'), given that 'se entenderá como comunidades indígenas a los conjuntos de familias que se reconozcan como tales por el hecho de descender de poblaciones que habitaban el territorio nacional en la época de la conquista o colonización' ('the groups of families that are recognized as such by the fact of descending from populations who inhabited the national territory in the time of the conquest or colonization will be considered as indigenous communities') (quoting in part the definition of Art 2 of Ley 23,302). Recognizing the occupation of the land by the indigenous community concerned, the judge thus ordered the defendants to refrain from committing 'todo acto que perturbe la ocupación de los actores en la zona de la veranada que dio motivo a estas actuaciones debiendo ocurrir por la vía y forma correspondiente para hacer valer los derechos que crean tener' ('all acts disturbing the occupation by the claimants of the zone of the veranada which triggered their legal claims, that must respect the correct means and forms to exercise the rights they deem to be entitled'). In this way the judgment recognised not only the possibility of hindering the movement of fences in indigenous lands (often carried out during the night), but also that the community itself is authorised immediately to remove such fences, on the condition that it effectively exercises 'la posesión o la tenencia efectiva' of the land concerned and that there is a temporal proximity between the setting up of the fences and their removal. This conclusion was based on Art 2470 of the Código Civil, which states that:

[e]l hecho de la posesión da el derecho de protegerse en la posesión propia, y repulsar la fuerza con el empleo de una fuerza suficiente, en los casos en que los auxilios de la justicia llegarían demasiado tarde; y el que fuese desposeído podrá recobrarla de propia autoridad sin intervalo de tiempo, con tal que no exceda los límites de la propia defensa.

([t]he fact that the possession exists gives its holders the right that it is legally protected, as well as to resist the attempts to forcibly discard it through using the necessary force, in the cases in which help from the competent authorities would arrive too late; and those who were dispossessed of it will be able to recover it through using their own authority immediately, provided that it does not exceed the limits of proper defence)

The judgment in the case of Quintriqueo, Joséc/Newbery, Tomáss/Acción autónoma de nulidad de sentencia ${ }^{20}$ of June 2003 is an extremely interesting example of jurisprudence, not only in view of the affirmation of claimed indigenous rights,

20 Expte. 14.446 del Juzgado civil de la IV Circunscripcuión judicial de la provincia de Neuquén of 3 June 2003. 
but also because it grants their concrete enforcement. The decision declared void a previous judgment issued by a judge of Junín de los Andes, who had sentenced the removal of the Mapuche Quintriqueo community from the territory of Paso Coihue after recognising the heir of a US citizen as the legitimate owner of that land. This person had received the land concerned from the Argentine government as a gift to express gratitude for funding the anti-indigenous campaign at the relevant time. The immediate restitution of the land to the community concerned was also ordered as a precautionary measure, which was actually carried out. As emerges from the reading of the judgment, Justice Farias held that:

atento las razones y el derecho invocado, normas de rango constitucional traídas, y a fin de evitar perjuicios inminentes a los pobladores del paraje Paso Coihue... disponese con caracter de medida cautelar innovativa, la restitución de la situación fáctica del lugar a la existente con anterioridad al 15 de mayo de 2003, suspendiendose la orden de desalojo dispuesta en autos 'Newbery c/Quintriqueo s/Desalojo' hasta tanto exista resolución en las presentes actuaciones'.

(having considered the claimants' reasons and the invoked right, that norms of constitutional status have been infringed, and in order to avoid imminent damage to the settlers of the place called Paso Coibue... it is decided, as an innovative precautionary measure, to order a return to the previous situation of the place before 15 May 2003, the order of eviction decided in 'Newbery c/Quintriqueo s/Desalojo' being suspended, as far as a solution exists for the actions performed.)

He added finally that the same judge who 'diligenciara el desalojo ... debería hacer entrega de la tenencia del predio a los pobladores de la Comunidad Quintriqueo, labrandose acta de todo lo actuado' ('will manage the eviction notice... should do so by making available the tenancy of the property to the settlers of the Community Quintriqueo, taking record of everything operated').

Finally, a more recent decision was enacted in August 2004 by Justice Riat in the case Sede Alfredo y otros c/Vila, Herminia $y$ otros s/desalojo. ${ }^{21}$ This judgment recognised the right 'de posesión indígena' with respect to property titles granted by the state, dismissing a claim for removal requested by the Sede family with regard to some members of the Mapuche community Kom Kiñé Mu of Arroyo de las Minas, who have for a long time occupied an area of land called Marcos Fernández. ${ }^{22}$ The main argument on which the judgment is based relies on the prevalence of the national Constitution over the civil code, that is to say on the primacy of the concept of 'preexistencia étnica' over property titles. As a consequence, despite the fact that the Sede family owned a property title granted by the former governor of the Masaccessi province, removal of Mapuche

21 Expte. 14012-238-99, Juzgado Civil y Comercial n. 5 de la III Circunscripción Judicial de Río Negro.

22 The land at stake had been donated in 1900 to the cacique (local political leader) —in this case, Ancalao-by a decree of President Roca, as a reward for having cooperated in the Conquista del desierto. Occupation by the Reserva Ancalao was later recognised by provincial legislation. 
families resulted as being 'improcedente porqué la posesión de los demandados (Mapuches) es necesariamente anterior a los títulos de los actores (flia Sede) ya que incluso es anterior a la formación misma del Estado que los confirió' ('inappropriate because the possession of the defendants (Mapuches) necessarily precedes the title of the claimants (flia Sede) since the possession existed even before the formation of the State that granted such titles'. The judge also clarified that:

la posesión comunitaria de los pueblos indígenas no es la posesión individual del Código civil. Por mandato operativo, categórico e inequívoco de la Constitución nacional, toda ocupación tradicional de una comunidad indígena debe juzgarse como posesión comunitaria aunque los integrantes no hayan ejercido por sí los actos posesorios típicos de la ley inferior (Código civil, art. 2384). Es la propia Constitución la que nos dice que esas comunidades han poseído y poseen juridicamente por la sencilla razón de preexistir al Estado y conservar la ocupación tradicional.

(the communitarian possession of indigenous peoples does not correspond to the form of individual ownership provided for by the civil Code. Pursuant to an operational, categorical and unequivocal order of the national Constitution, any traditional occupation of an indigenous community must be considered as community possession although its members have not practised it by means of the typical acts qualifying ownership according to subordinate law (civil Code, art. 2384). It is precisely the Constitution which tells us that these communities have possessed and possess legally [the land] for the simple reason of pre-existence to the State and of preserving their traditional occupation')

Recalling the pertinent doctrine, ${ }^{23}$ the judge finally emphasized that:

la protección consagrada para la propriedad de las comunidades indígenas argentinas por el artículo 75 inc. 17 de la Constitución Nacional hace innecesaria e inconveniente su inclusión en el Código civil, ya que ello implicaría una desjerarquización no querida por el poder constituyente.

(the protection granted with respect to the ownership of Argentine indigenous communities by article 75 inc. 17 of the National Constitution makes its inclusion in the civil Code unnecessary and inopportune, since it would imply a de-hierarchicalization not desired by the constituent power')

The particular significance of this decision rests on the fact that recognition of the pre-existence of local indigenous peoples to the Argentine state implies that 'el derecho objetivo ha cambiado' and that-as pointed out by Rodríguez Duchthe indigenous question is now to be resolved by relying on 'la nuevas normas de derecho público dictadas especificamente, aun en contra de las viejas normas de derecho privado, tales como el Código civil'.24

Finally, also in 2004, the judgment ComunidadMapuche Huayquillan c/Brescia, Celso Armando y otro $^{25}$ recognised the ownership of a piece of land acquired

23 The judge referred, in particular, to Jorge Alterini, Pablo Corna, and Alejandra Vázquez.

24 See D Rodríguez Duch, 'El derecho de las comunidades originarias en las decisiones jurisprudenciales', in Derecho de los Pueblos Indigenas - Derecho de las comunidades, available at <http:// www.indigenas.bioetica.org>.

25 Judgment of 18 August 2004 of the Juzgado en lo Civil, Comercial, Laboral y de Mineria de Chos Malal, provincia de Neuquén. 
through adverse possession by a Mapuche community which demonstrated that it had occupied the claimed territory-continuously and peacefully-for over forty years, through the construction of houses and constant agricultural activity. The finding was based on sentence 17 of Art 75 of the Constitution, on the ILO Convention No 169, and on the regulation of adverse possession by the civil code in force at the relevant time.

\section{d) The request for protection of the environment by Argentine autochthonous communities}

Some indigenous communities of Argentina have submitted actions of amparo, ${ }^{26}$ claiming that their natural environment is threatened by certain projects of deforestation, exploitation of surface and sub-surface resources, as well as by the construction of great public works and infrastructures.

In September 2004 the judgment released by the Juzgado Civil de Primera Instancia de Junín de los Andes in the case Comunidad Mapuche Paichil Antreao y otro c/Prov. del Neuquén s/ Acción de Amparo ${ }^{27}$ imposed the suspension of the indiscriminate felling of trees and extraction of volcanic materials from the slopes of Cerro Belvedere, in Villa La Angostura. The Mapuche community Paichil Antreao, although it did not have 'personería jurídica inscripta', had presented an amparo action with the assistance of the Centro de Derechos Humanos y Ambiente, maintaining that deforestation would lead to the extinction of rare and ancient plant species, with the addition of damage caused by the works of extraction. They also emphasised that the sacredness of the land concernedwhere the community had performed its religious practices and ceremonies since time immemorial—would be violated. The judgment recognised the legitimacy of the claim presented by the community concerned 'aún sin personería jurídica inscripta'. In consideration of the fact that 'la erradicación de bosques disminuye la diversidad biológica y destruye los pulmones que ayudan a regenerar la tierra', and pursuant to Art 41 of the national Constitution (recognizing the right to protection of one's own environment) it decided that the felling of trees and extractive operations had to be stopped within ten days.

\footnotetext{
26 Section 43, para 1 of the national Costitution states that ' $\mathrm{t}$ ] oda persona puede interponer acción expedita y rápida de amparo, siempre que no exista otro medio judicial más idóneo, contra todo acto u omisión de autoridades públicas o de particulares, que en forma actual o inminente lesione, restrinja, altere o amenace, con arbitrariedad o ilegalidad manifiesta, derechos y garantías reconocidos por esta Constitución, un tratado o una ley. En el caso, el juez podrá declarar la incostitucionalidad de la norma en que se funde el acto u omisión lesiva' ('Ca]ny person shall file a prompt and summary proceeding regarding constitutional guarantees [amparo], provided there is no other legal remedy, against any act or omission of the public authorities or individuals which currently or imminently may damage, limit, modify or threaten rights and guarantees recognized by this Constitution, treaties or laws, with open arbitrariness or illegality. In such case, the judge may declare that the act or omission is based on an unconstitutional rule' (official translation)).

27 Expte. 15.320/03 del Juzgado Civil y Comercial de la IV Circunscripción Judicial del Neuquén.
} 
Also in the context of environmental protection, the judgment Comunidad Indigena del Pueblo Wichi Hoktek TOI c/ Secretaria de Medio Ambiente y Desarrollo Sustentable of 2002 is worth mentioning, which is of particular importance for the fact of its being released by the national Supreme Court of Justice. It recognised the right of the Wichi Hoktek T'OI community to submit an amparo action before the Court of Justice of the Salta province, in order to obtain the cancellation of two administrative acts released by the Secretaría Provincial de Medio Ambiente y Desarrollo Sustentable, authorizing 'la deforestación indiscriminada' of a given area bordering the land inhabited by the indigenous community concerned. The local tribunal had rejected the amparo action, holding that, in order to obtain the cancellation of the aforementioned administrative acts, the interested community had to rely on available administrative or judicial procedures. The Supreme Court, on the contrary, held that the provincial tribunal should grant the amparo action-precisely on account of the likely and irreparable damage to the environment caused by deforestation (including the extinction of certain animal species as well as the possible alteration of the climate and the soil). It was in fact a matter of 'una efectiva protección de derechos' of the community concerned that could not adequately be safeguarded through ordinary means of recourse.

\section{Chile}

\section{a) Indigenous peoples of contemporary Chile}

The situation of the indigenous peoples living in the territory of Chile is very different from that of Argentina. Neither their existence nor a set of rights in their favour have yet been recognised by the Constitution. In addition, Chile has not ratified ILO Convention No 169 on Indigenous and Tribal Peoples in Independent Countries. ${ }^{28}$

With regard to the nineteenth century, the story of relations between Chile and the local autochthonous populations is similar to nearby Argentina's in a number of respects. Between 1860 and 1883 Chile also extended its control over

28 According to the census of 2002, at that time the total population of Chile amounted to $15,116,435$ people, including 692,192 (4.6 per cent) of inhabitants who declared that they belonged to an indigenous group (87.3 per cent of them were of Mapuche origin and 12.68 per cent belonged to other ethnic groups, ie Alacalufe/Kawéskar, Atacameno/Lickanantay, Aymara, Colla, Quechua, Rapa Nui e and Yámana; these numbers do not include the Diaguita community, which has not been recognised as indigenous by law and is thus not considered in the census). The previous census, held in 1992, indicated that 998,385 people over the age of 14 had declared that they belonged to an indigenous population; this number jumped to 1,350,000 if children under 14 years old were also considered, amounting to 10 per cent of the total population. See J Aylwin, 'Implementación de legislación y jurusprudencia nacional relativa a los derechos de los pueblos indígenas: la experiencia de Chile, Observatorio de Derechos de los Pueblos Indígenas, Documento de Trabajo n. 3, available at <http://www.observatorioderechosindigenas.cl $>$. 
some austral territories (previously belonging to the Aonikénk and Selknam communities), making those lands available for European investors through a process defined by Chilean historians as la Pacificación de la Araucania. The lands belonging to the Mapuche were occupied through recourse to the army. The Mapuche were thus stripped of their ancestral lands and confined to some 3,000 reservations which were concentrated into 5 per cent of the area of the territory they originally occupied. Here too the rest of the territories were placed at the disposal of foreign investors and large landowners.

The twentieth century saw in a number of laws promoting the partition and subsequent sale of lands included in the Mapuche reservations, without granting the Mapuche any right of pre-emption. Land partition (and the subsequent division of the community) 'era la única manera de incorporar [los indígenas] plenamente a la civilización', as explained by a Decree-law (No 266) of 1931.

The presidency of Allende represented a short parenthesis in the indigenist policy of those years. Indeed in 1972 Ley Indigena n. 17.729 providing for the restitution of lands was enacted (which was actually carried out with regard to some 60,000 hectares), and this law established the Instituto de Desarrollo Indígena-with the task of 'promover el desarrollo social, educacional y cultural de los indígenas de Chile, considerando su idiosincrasia y respetando sus costumbres' (art 38) — granting support for social and cultural rights and ensuring the teaching of the Mapudungun ${ }^{29}$ language together with Spanish.

During the regime of Pinochet (1973-1990) — whose motto 'no existen poblaciones indígenas, somos todos chilenos' is well-known-the process of the division and sale of indigenous lands restarted with two decree-laws enacted in $1979,{ }^{30}$ which established that the indigenous reservations that still existed at that time had to be sold in the form of individual lots. They also specified that 'las hijuelas resultantes de la división de las reservas dejarán de considerarse indígenas, e indígenas sus adjudicatarios'. In addition, the Código de Aguas of 1981 authorised the government to grant rights over surface and subsurface waterways in favour of private individuals also in the lands inhabited by indigenous communities, harming in particular the Aymara of the North in favour of certain mining enterprises.

After the end of the Pinochet regime, new institutions started a timid and undefined policy for indigenous communities, which had just started to organize themselves in order to claim their own rights and promote their protection. In 1993 the Congress approved the Ley 19.253 sobre Protección, Fomento y Desarrollo de los Indigenas-better known as Ley Indigena-which at that time was certainly an important result, despite some contradictions in its text. Indeed the law in question established the Corporación Nacional de Desarrollo Indígena (CONADI), an institution which includes a minority of indigenous

29 See J Garrido et al, Historia de la reforma agraria en Chile (Santiago de Chile, 1990).

30 Decree laws No 2568 and No 2750. 
representatives amongst its members. This should ensure that it actually works to safeguard indigenous rights adequately.

On the other hand, however, it recognised indigenous peoples simply as 'ethnic groups' and not as 'populations'. Moreover, it did not include a clear catalogue of the political and territorial rights accorded to them. Furthermore, the law restricted the right of association of indigenous communities to 'comunidades territoriales' or 'asociaciones funcionales', which, however, are not allowed to group themselves into federations. With regard to indigenous lands, the law established that this term may be recognised only for those lands that 'las personas o comunidades indígenas actualmente ocupan en propriedad o posesión' on the basis of titles recognised to the communities by the state (Art 12), those which are officially registered in the Registro de Tierras Indígenas or those that are expressly declared as possessing these characteristics by domestic courts.

The fact that lands cannot be 'enajenadas, embargadas, gravadas, ni adquiridas por prescripción' is also stressed (Art 13). In addition-by virtue of a Fondo de Tierras y Aguas Indigenas - the possibility of obtaining an allowance for the purchase of lands is provided. This allowance may also be obtained in view of determining - in the event of a controversy — what rights actually exist over waters, as well as with the aim of facilitating the acquisition of public lands by the claimant communities. The law, however, neither incorporated the concept of 'territorialidad indígena' established by ILO Convention No 169 nor recognised indigenous rights over natural resources, which have recently acquired considerable importance in the context of indigenous claims. It may be interesting to note that the law contemplated the possibility of 'permutar por tierras de no indígenas, de similar valor comercial debidamente acreditado, las que se consideraran tierras indígenas, desafectándose las primeras' ('to exchange indigenous lands for non-indigenous ones, of similar commercial value properly credited, which will be considered to be indigenous lands'), with the authorization of CONADI.

In addition to the Ley Indigena, two more proposals were advanced in 1993; namely the ratification of ILO Convention No. 169 and the inclusion of an amendment in the national Constitution which explicitly recognised indigenous rights. Both proposals were rejected at that time and again in 2005, when President Lagos presented them to the National Congress. However, President Lagos laudably tried to inaugurate a 'new phase' in the relationship between the government and the autochthonous communities. In 2001 he established the Comisión de Verdad Histórica y Nuevo Trato, which, through the Informe released in 2003, recognised the mistakes and contradictions that had characterised the past indigenist policy, renewing the invitation to ratify Convention No 169 and to reform the Constitution. The Informe also established certain economic measures aimed at supporting the indigenous peoples.

The proposal of constitutional reform put forward in 2005 may represent a significant first step forward in the national policy concerning indigenous people. However it did not contemplate any specific reference to collective political, cultural 
and territorial rights, as suggested by the Comisión ${ }^{31}$, which had proposed the inclusion of the following provision:

la ley garantizará el derecho a conservar, desarrollar y fortalecer la identidad, idiomas, instituciones y tradiciones espirituales, sociales y culturales de los pueblos indígenas que habitan el territorio nacional.

the law will ensure the right to preserve, develop and strengthen the identity, languages, institutions, and spiritual, social and cultural traditions of the indigenous peoples who inhabit the national territory

\section{b) The problem of safeguarding indigenous rights over lands and natural resources in contemporary $\mathrm{Chile}^{32}$}

Today, protection of the ownership of ancestral lands occupied by indigenous peoples in Chile is limited. This is due to the lack of express recognition of such rights in the Constitution or other normative texts. In addition, economic and political interests lead governmental institutions to pursue an indigenist policy that is undefined and often contradictory. Since the 1990s the Chilean economy has opened up to national and foreign investments, both public and private, which often have lands inhabited or claimed by indigenous communities as their target. The resulting clash among opposing irreconcilable interests is self-evident, since the rights claimed by indigenous peoples are, in addition to the ownership of ancestral lands, ${ }^{33}$ the rights of exploitation and management of natural

31 The Comisión de Verdad Histórica y Nuevo Trato in the Informe of 2003 recommended modifying the Constitution so as to affirm 'la existencia de lo Pueblos Indígenas, que forman parte de la nación chilena, y reconozca que poseen culturas e identidades proprias'; 'que los Pueblos Indígenas de Chile son descendientes de las sociedades precoloniales que se desarrollaron en el territorio sobre el que actualmente el Estado chileno extiende su soberanía, a las que estan ligadas por una continuidad histórica'; and 'establezca el deber del Estado de garantizar la preservación de la diversidad étnico cultural de la nación y, por consiguiente, la preservación y el ejercicio de la cultura y la identidad de los Pueblos Indigenas con pleno respeto de la autonomía de sus miembros; y que en consonancia con dicha declaración, reconozca y garantice el ejercicio de un conjunto de derechos colectivos a favor de los pueblos indigenas' ('the existence of the Indigenous Peoples, which are a part of the Chilean nation, and admit that they possess their own cultures and identities'; 'that the Indigenous Peoples of Chile are descendants of the pre-colonial societies who developed in the territory on which at present the Chilean State extends his sovereignty, to which they are tied by historical continuity'; and 'to establish the duty of the State to guarantee the preservation of the ethnical-cultural diversity of the nation and, consequently, the preservation and the exercise of the culture and the identity of Indigenous Peoples with full respect of the autonomy of their members; and that, consistently with the foregoing, to recognize and guarantee the exercise of a set of collective rights in favour of indigenous peoples') (Cuerpo III, p. 127; see Aylwin, op cit, n 39).

32 According to data collected in 2005, new lands were assigned to indigenous communities through the CONADI and the Ministerio de Bienes Nacionales, and their ownership over the lands they already occupied was recognised. The assigned lands amounted to a total of 384,150 hectares, including 75,000 hectares of new lands.

33 For example, the construction of the hydro-electric power plant at Ralco in upper Bío Bío, completed in 2004, led to the flooding of a land ancestrally inhabited by the Mapuche Peuhenche, who opposed the project in vain and who were eventually displaced to another territory. In 2003, 
resources and surface and subsurface watercourses, which are essential for the survival of the communities concerned. ${ }^{34}$ In more recent years, pursuant to the afore-mentioned Código de Aguas, the government has granted private persons and operators a right of free and perpetual supply of waters, keeping them out of the indigenous communities' control. Nevertheless, on 4 October 2004, for the first time, the Supreme Court ruled in favour of an indigenous community in this respect. In the case concerning la Atacameña de Toconce, of the II Región de Antofagasta, the Court recognised 'la propriedad ancestral indígena sobre las aguas, derivadas de prácticas consuetudinarias, [que] constituye dominio pleno por aplicación del los artículos 3 transitorio, inciso $2^{\circ}$ y 64 de la Ley Indígena' ('the ancestral indigenous ownership of the waters derived from customary practices, falling within the scope of application of transitory article 3, No 2 and article 64 of the Indigenous Law') ${ }^{35}$ rejecting the claims of the Empresa Sanitaria y de Servicios de Antofagasta ESSAN S.A.

The contradictory policy of the government and the lack of recognition of indigenous rights has triggered a number of protest rallies, demonstrative actions and cases of land occupation by indigenous dissidents, leading the institutions to react very harshly. At the legislative level, the Congress has blocked the process of ratification of ILO Convention No 169 and any other ongoing process of proindigenous constitutional reform. Furthermore, police forces have used excessive violence to repress protest marches by indigenous people, thus being accused of violating the fundamental human rights of demonstrators. ${ }^{36}$ Finally, the antiterrorism legislation in force (Ley antiterrorista $\left.n^{\circ} 18.314\right)^{37}$ has been applied with regard to some of the arrested indigenous activists, limiting their right to due

five Peuhenche women reported on the situation to the Inter-American Commission on Human Rights, claiming violation of their rights, including the right to life and the right to private property. Thanks to the mediation by the Commission an agreement was finalised, which contemplated the reparation of pecuniary damages, restitution of claimed lands, improvement of participation by the Peuenche in the management of natural resources for their own development, as well as the promise to reopen negotiations for constitutional reform and the ratification of ILO Convention No 169.

34 For example, in order to favour the exploitation of ore deposits located in the Northern part of the country, in areas inhabited by indigenous communities (Aymara, Quechua, Lickanatay, Coya, and Diaguita), the government ceded these areas and recognised the right to use and exploit watercourses, including underground ones, to non-indigenous people. In addition, intense plant cultivation aimed at producing precious wood modified the local landscape, environment, flora and fauna of some lands belonging to the Mapuche, leading to the exhaustion of freshwater reserves on and under the ground.

35 Judgment quoted by J Aylwin, Implementación de legislación y jurusprudencia nacional relativa a los derechos de los pueblos indígenas: la experiencia de Chile, Observatorio de Derechos de los Pueblos Indígenas, Documento de Trabajo n. 3, available at <www.observatorioderechosindigenas.cl>.

36 Human Rights Watch and Observatorio de Derechos de los Pueblos Indigenas (2004) denounced cases of mistreatment perpetrated by the police while performing body searches and anti-uprising operations. Cases of torture were also reported, and a young person was killed in 2002 by a bullet shot by an agent of the Carabineros.

37 Only in the Araucaria region 300 Mapuche were charged with taking part in protest marches aimed at defending their land; 10 per cent of them were indicted for acts of terrorism. 
process and leading to disproportionate convictions which were upheld by the Supreme Court. Against this trend, however, the judgment released in July 2005 by the Tribunal Oral en lo Penal de Temuco is worth mentioning, which rejected the charge of 'asociación ilícita terrorista' for a group of Mapuche. In doing this, the Tribunal specified that:

cualquier definición de terrorismo que se quiera enunciar debe necesariamente contener el concepto de desprecio a la vida humana, propria o ajena, concepto que no resulta del contenido de los hechos que se relataron en la audiencia. ${ }^{38}$

whatever definition of terrorism one wants to use, it must necessarily include the concept of scorn to human life, of his/her or another person's own, a concept that does not result from the content of the facts that were reported in the hearings

Similarly, the application of the Ley antiterrorista to the aforementioned cases was criticised on 7 April 2006 by the Tribunal de lo Penal de Angol, which acquitted the defendants from the charge of 'incendio terrorista', with respect to the areas of Poluco and Pidenco, on the basis of the fact that

la presunción simplemente legal establecida en el artículo $1^{\circ}$ de la Ley n. 18.314, relativa a la finalidad de producir en la población o en una parte de ella temor justificado de ser victimas de delitos de la misma especie, se encuentra en abierta contraddicción con el derecho a la presunción de innocencia que en nuestro país tiene rango constitucional por estar incorporado en los tratados internacionales ratificados por el Chile, que nuestra Carta fundamental asegura respetar y garantizar en el inciso segundo de su artículo $5^{\circ} .39$

the legal presumption established by Art 1 of the Lawn. 18.314, relating to the purpose of triggering in the population, or in a part of it, a well-founded fear of being a victim of the same sorts of crimes, is in clear contradiction to the right to be presumed innocent that in our country has constitutional status for being incorporated in the international agreements ratified by Chile, that our fundamental Law prescribes to be respected and guaranteed in the second paragraph of its article 5

In reaching this conclusion, the Tribunal expressly referred to Art 8.2 of the American Convention on Human Rights and to Art 14.2 of the International Covenant on Civil and Political Rights. Whereas the Tribunal does not possess the competence to declare the Ley antiterrorismo to be unconstitutional, it considers this law as part of a legal system - the Chilean one-in which such treaty provisions are (rectius: should be) in force, explaining that:

[s]e debe tener presente respecto de la presunción legal del artículo $1^{\circ}$ de la ley 18.314 , en la cual el legislador asume que la conducta de las personas es constitutiva de delito terrorista prescindiendo de una investigación, de un juicio, vulnerando tratados internacionales ya antes mencionados y la propia ley procesal, es por ello que en la especie nos encontramos ante un caso en que el legislador, sin procedimiento alguno asume la intención volitiva de

38 Sentencia del Tribunal Oral en lo Penal de Temuco, RUC 02001424 99. RIT 080/2004 of 27 July 2005. See FIDH, Informe. Chile. Posibilidades de cambio en la politica hacia los pueblos indigenas, August 2006.

39 Emphasis added. 
los acusados de querer infundir temor en la población o arrancar decisiones de la autoridad... la presunción simplemente legal no es propriamente un medio de prueba, sino que consituye un caso de inversión del onus probandi que favorece a quien la invoca y pone a cargo de la otra parte la prueba en contrario. ${ }^{40}$

[t] he legal presumption set up by article 1 of the law 18.314 is to be taken into account, in which the legislator establishes that the conduct of the person is constitutive of a terrorist crime leaving aside any investigation or judgment, breaching the aforementioned international agreements and procedural law, and for which we are dealing with a case in which the legislator, without any procedure, presupposes the will of the accused person to instil fear in the population or to force the authority to take certain decisions... the simply legal presumption is not properly a means of proof, but constitutes a case of reversal of the onus probandi which favours the party who invokes it and forces the other party to provide evidence to the contrary.

\section{Conclusion}

While by no means exhaustive, this chapter has aimed to describe the current status of indigenous rights in Argentina and Chile, with particular attention to reparatory measures that, where taken, have been granted or promised by the two countries.

With regard to Argentina, we may say that since the affirmation of indigenous rights in the constitutional reform of 1994, certain steps have been taken in terms of reparations for the indigenous peoples, although these have been limited in most cases to the form of mere recognition of indigenous property rights over ancestral lands. This has happened in Patagonia especially, where most cases of expropriation of indigenous lands occurred. In some cases even the restitution of indigenous lands, previously misappropriated by non-indigenous persons, has been ordered. ${ }^{41}$

As for Chile, the general picture resulting from this chapter is that of a country in arrears with regard to both the recognition and the affirmation of indigenous rights. Unfortunately, at the moment the Chilean government shows no intention of adopting a different approach, and it persists in pursuing a policy in favour of non-indigenous interests, whether these are public private. However, signs of a counter tendency have recently come from some local courts (particularly with regard to the application of the Ley antiterrorismo to indigenous dissidents). ${ }^{42}$ This is perhaps a harbinger of change and it may prove significant as it is coming from judges, who are the ones with the primary role in ensuring the concrete recognition, granting and safeguarding of individual and collective rights.

40 cf FIDH, Informe. Chile. Posibilidades de cambio en la politica hacia los pueblos indígenas, August 2006.

41 See para 1(c), above.

42 See para 2(b), above. 